\title{
Segments vs. Clusters: Postaspiration in Sevillian Spanish
}

\author{
Madeline Gilbert \\ New York University
}

\section{Introduction}

Sevillian Spanish (Western Andalusian, Southern Spain ${ }^{1}$ ) is undergoing a change from preaspiration to postaspiration in /s ptk/ sequences. Coda/s/ weakening is common in Sevillian Spanish, leading to aspiration, deletion, and postaspiration (Ruch, 2008; Villena-Ponsoda, 2008). In postaspirated forms, coda /s/ is realized as VOT on the following voiceless stop. Postaspiration occurs morpheme internally (Table 1a), and is also reported across morpheme (Table 1b) and word boundaries (Table 1c) (Horn, 2013).

Table 1: Postaspiration in /s ptk/ sequences in Western Andalusian Spanish

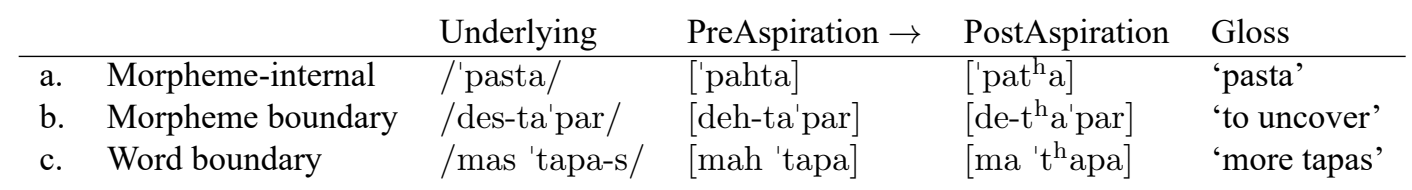

Postaspiration can co-occur with preaspiration and gemination of the following consonant within a single production of a word (e.g. ['paht(: $)^{\mathrm{h}}$ a]) (Ruch, 2008; Ruch \& Harrington, 2014). Furthermore, aspiration, deletion, gemination, and postaspiration are variable within and across speakers (Ruch \& Harrington, 2014; Ruch \& Peters, 2016). I use preaspiration and postaspiration descriptively, without implying a phonological analysis in which [h] belongs to the consonant.

There are two possible interpretations of postaspiration. Postaspirated stops are either surface variants of underlying $/ \mathrm{sC} /$ clusters (metathesis), or a new series of postaspirated stops $\left(/ \mathrm{C}^{\mathrm{h}} /\right)$. I use the word sequence to refer to adjacent sounds, without implying a particular phonological analysis (/h t/, with a space). Cluster refers to a sequence of two independent sounds that occur adjacent to each other (/ht/, no space). Complex segment refers to a sequence of sounds analyzed as a single consonant $\left(/{ }^{\mathrm{h}} \mathrm{t} /, / \mathrm{t}^{\mathrm{h}} /\right.$, superscript). I do not make these distinctions in surface forms, which do not make representational claims.

In this paper, I provide evidence for two points. (1) Sevillian postaspiration derives from an underlying $/ \mathrm{sC} /$ cluster. These forms have not phonologized into a series of postaspirated stops. I propose that this is, in part, due to two sources of allophonic variation: socially-conditioned variation and morphophonemic alternations across word and morpheme boundaries. (2) Sevillian listeners perceive postaspiration, and they map it back to what we know to be an underlying /sC/ cluster. Previous studies have found that Sevillian listeners perceive and use postaspiration in lexical decision and word identification tasks (Ruch \& Harrington, 2014; Bedinghaus, 2015). However, these studies focus on word-internal /s ptk/ sequences, where there is no evidence for the underlying order. I also present a perception study that builds on previous work by testing perception across word boundaries, providing evidence that Sevillian listeners can hear postaspiration and interpret it as deriving from $/ \mathrm{sC} /$ clusters.

\footnotetext{
* I would like to thank Maria Gouskova, Lisa Davidson, Gillian Gallagher, Juliet Stanton, and Joseph Casillas for support and helpful comments on this work. Thanks also to the NYU PEP Lab and audiences at AMP 2020.

1 I use the term Sevillian Spanish to refer to the Spanish spoken in Seville, which is where participants in my study live. I use the broader, regional term Western Andalusian Spanish (WAS) in discussing previous work, much of which does not further specify which cities their participants come from. There may be significant dialectal variation. Finally, I use Andalusian to refer generally to the dialects spoken in Southern Spain.
}

(C) 2021 Madeline Gilbert

Proceedings of AMP 2020 
The remainder of the paper is as follows. In Section 2, I argue that Sevillian postaspiration is an underlying cluster, based on socially-conditioned variation and morphophonemic alternations. Section 3 introduces the methodology and predictions of the perception experiment, and Section 4 presents the results. To preview, Sevillian listeners perceive and make use of VOT to distinguish a morphological difference, while listeners of another dialect (Mexican Spanish) do not. In Section 5, I outline an analysis in which postaspiration is the result of gradual coda reduction followed by metathesis, possibly due to perceptual factors. Section 6 concludes.

\section{Sevillian postaspiration is an underlying cluster}

2.1 Representational status of postaspiration Surface postaspiration in Sevillian Spanish provides ambiguous evidence of whether its underlying representation is a cluster $/ \mathrm{sC} /$ or a postaspirated stop $/ \mathrm{C}^{\mathrm{h}} /$. Listeners hear ['pat ${ }^{\mathrm{h}} \mathrm{a}$ ], and could posit representations like /'pat ${ }^{\mathrm{h}} \mathrm{a} /$ or /'pasta/. If they hear ['pat ${ }^{\mathrm{h}} \mathrm{a}$ ], what would lead them to posit /'pasta/ as the underlying representation?

Some scholars have argued that Sevillian postaspiration is phonologizing into a series of aspirated stops $/ \mathrm{p}^{\mathrm{h}} \mathrm{t}^{\mathrm{h}} \mathrm{k}^{\mathrm{h}} /$. It is not always clear if they intend this claim as phonetic or phonological. For example, Gylfadottir (2015) argues that postaspiration and preaspiration are distinct variants (articulatory targets), but also refers to postaspiration as 'phonological reanalysis.' Her arguments are mainly phonological. One is that postaspiration can surface phrase-initially, but Spanish generally disallows onset clusters with $/ \mathrm{s} /$. She points out that a word like /es'ta/ 'is-3sG' can be produced phrase-initially as [' $\mathrm{t}$ ha], without the first vowel. Analyzing postaspiration as an aspirated stop avoids violating the restriction against onset clusters with $/ \mathrm{s} /$. However, it seems that [' $\mathrm{t}^{\mathrm{h}} \mathrm{a}$ ] could plausibly be derived from an underlying cluster in a word where the initial vowel is deleted due to extra-linguistic factors (/es'ta/ $\rightarrow[$ eh'ta $\left.] \rightarrow\left[e^{\prime} t^{h} a\right] \rightarrow\left[{ }^{\prime} t^{\mathrm{h}} \mathrm{a}\right]\right)$. Furthermore, it is not clear how frequent phrase-initial postaspiration is.

A second argument in favor of analyzing postaspirated stops as single segments is the further change from postaspiration to postaffrication in some Andalusian varieties (/'pasta/ $\rightarrow$ ['pat $\left.{ }^{\mathrm{h}} \mathrm{a}\right] \rightarrow\left[\right.$ 'pat $\left.^{\mathrm{s}} \mathrm{a}\right]$ ) (Moya Corral, 2007; Ruch, 2012; Del Saz, 2019). Gylfadottir (2015) takes this to be fortition, which seems to require that the underlying representation is an aspirated stop $/ \mathrm{t} /$. A similar change in British English has been analyzed as fortition $\left(/ \mathrm{t} /:\left[\mathrm{t}^{\mathrm{h}}\right] \rightarrow\left[\mathrm{t}^{\mathrm{s}}\right]\right.$ ) (Buizza \& Plug, 2012). English /t/ is underlyingly aspirated, so fortition can target one of its features.

A third argument comes from duration measurements. O'Neill (2009) argues that an 'underlying aspirated occlusive phoneme' contrasts with an occlusive phoneme, such that the same word has two representations (/'pasta/, /'pat ${ }^{\mathrm{h}} \mathrm{a} /$ ). He argues for contrastive postaspiration based on the duration of the components. The duration of the stop closure and the preceding vowel differ in postaspirated and preaspirated forms. More specifically, the vowel preceding the stop in postaspirated forms $\left(\left[\mathrm{V} \cdot \mathrm{t}^{\mathrm{h}} \mathrm{V}\right]\right)$ is similar in duration to that in words with a preceding open syllable ([V.tV]), suggesting that the postaspirated forms have an underlying open syllable too. However, other studies find slightly different (and inconsistent) results (Gerfen, 2002; Torreira, 2006; Ruch \& Peters, 2016). Durational measurements are not always clear arguments for underlying structure, and complex segments affect preceding vowels differently in different languages (e.g. for prenasalized stops, Riehl, 2008; see Stanton, 2017:29 for summary table).

Previous work suggesting phonological reanalysis does not define phonological reanalysis or phonologization clearly. Following Hyman (2013), I take phonologization to be the development of a phonetic feature (1) beyond what can be considered phonetically natural, and (2) into a phonologically active one. Contrasts often rely on multiple acoustic cues and non-primary, non-contrastive cues can become primary and contrastive over time. For example, contrastively nasal vowels can develop from contextual vowel nasalization adjacent to a nasal consonant (Beddor, 2009). If nasalization is reinterpreted as the primary cue, it can become contrastive and the nasal consonant often deletes. In Sevillian Spanish, the primary cue to the distinction between $/ \mathrm{V} \mathrm{s} \mathrm{t} \mathrm{V/and} / \mathrm{V} \mathrm{t} \mathrm{V/} \mathrm{could} \mathrm{be} \mathrm{shifting} \mathrm{to} \mathrm{postaspiration,} \mathrm{as} \mathrm{opposed} \mathrm{to} \mathrm{other} \mathrm{cues}$ (e.g. gemination, preaspiration). This postaspiration is longer than the phonetically natural release of a stop following /s/. However, although previous work has shown that Sevillian listeners perceive the distinction between /V s t V/ and /V t V/ based only on VOT manipulations (Ruch \& Harrington, 2014), this does not necessarily mean that the surface VOT belongs underlyingly to the stop, or that it is phonologically active.

I argue that Sevillian Spanish speakers have evidence that postaspiration derives from an underlying cluster. This evidence comes from sociolinguistic variation (Section 2.3) and morphophonemic alternations 
(Section 2.4). Both provide evidence that postaspriation is an allophonic realization of $/ \mathrm{s} /$, and that $/ \mathrm{s} /$ precedes /ptk/ representationally. Other scholars also argue against phonologization, although for different reasons (e.g. Parrell, 2012; Torreira, 2012). Before turning to sociolinguistic variation and alternations, I first discuss Spanish coda /s/ reduction, the process that gives rise to postaspiration.

2.2 Spanish coda reduction Coda/s/ lenition is the source of Sevillian postaspiration. Many Spanish dialects weaken coda /s/, leading to aspiration and deletion (Hualde, 2005; Erker, 2012; Campos-Astorkiza, 2016). Postaspiration has only been attested in Andalusian Spanish. I focus on weakening in preconsonantal coda position, since this is the position where /s/ weakening is cross-dialectally most common (Brown \& Torres Cacoullos, 2003), and where postaspiration arises in Sevillian Spanish.

Varieties of Spanish differ in which coda consonants they tolerate. Conservative varieties, like Standard Peninsular Spanish and Mexican Spanish, allow preconsonantal coda /s/ to surace as $[\mathrm{s}]([\mathrm{sC}] ;[\mathrm{zC}]$ when the following consonant is voiced). Other varieties, like Argentinian Spanish, are a step more restrictive: preconsonantal coda /s/ aspirates to [h] ([hC]) (Terrell, 1978). In even more restrictive varieties-like Dominican Spanish — deletion is the most common realization of preconsonantal coda /s/ ([ØC]) (Alba, 1990). The cline in (1) illustrates progressively tighter restrictions on coda consonants.

$\begin{array}{lll}\text { Mexican } & \text { Argentinian } & \text { Dominican } \\ \text { [pasta }] \rightarrow & \text { [pahta }] \rightarrow & \text { [pata] } \\ & & \text { Sevillian (Western Andalusian) } \\ & {\left[\text { 'pat }{ }^{\mathrm{h}} \text { a }\right]} \\ & \text { Eastern Andalusian } \\ & {[\text { 'pa }(\mathrm{h}) \mathrm{t}(\mathrm{:}) \mathrm{a}]}\end{array}$

Mexican Spanish is on the least restrictive end, and varieties like Dominican and Andalusian Spanish are on the most restrictive end. Across Andalusia, coda /s/ weakening leads to aspiration, gemination of the following consonant, and deletion (Penny, 2000; Gerfen, 2001, 2002; Campos-Astorkiza, 2003; O'Neill, 2010; Martinez-Gil, 2012). I consider postaspiration to be a response to restrictive coda requirements, because it solves the same problem that deletion solves: the intolerable coda $/ \mathrm{s} /$ is removed. These variants are socially and stylistically conditioned in Seville, and are described in the following section.

2.3 Sociolinguistic variation Sociolinguistic variation is one source of evidence for the underlying cluster analysis of postaspiration. Although Andalusian Spanish — and, more specifically, Sevillian Spanishseverely restricts coda $/ \mathrm{s} /$, learners of Sevillian Spanish are exposed to multiple variants of $/ \mathrm{s} /$, only some of which are realized as postaspiration. Non-postaspirated variants give learners evidence that postaspiration comes from underlying $/ \mathrm{s} /$.

Attested realizations of /s ptk/ sequences in Sevillian Spanish include aspiration, gemination, postaspiration, and deletion (2) (Torreira, 2006; Villena-Ponsoda, 2008; Ruch \& Harrington, 2014).

(2) Attested realizations of /s k/ sequences in /'boske/ 'forest' in Sevillian Spanish (categories adapted from Ruch, 2008; Ruch \& Harrington, 2014)
a. ['boske]
b. $\quad[\operatorname{bohk}(:) \mathrm{e}]$
(retention)
c. $\left[\right.$ 'bohk $\left.{ }^{\mathrm{h}} \mathrm{e}\right]$
d. $\left[\right.$ 'bok $\left.{ }^{\mathrm{h}} \mathrm{e}\right]$
e. ['bok:e]
(aspiration + variable gemination)
(aspiration + postaspiration)
(postaspiration/metathesis)
(deletion of $/ \mathrm{s} /+$ gemination)

In Seville, realizations of preconsonantal coda $/ \mathrm{s} /$ as [s], [h], and $\left.{ }^{\mathrm{h}}\right]$ are socially conditioned by factors like speaker age, sex, level of education, and speech style (Ruch, 2008; Ruch \& Peters, 2016). Learners hear the same word produced with all variants, which provides evidence that postaspiration is an allophonic variant of $/ \mathrm{s} /$ in an $/ \mathrm{sC} /$ sequence, not a single complex phoneme $/ \mathrm{p}^{\mathrm{h}} \mathrm{t}^{\mathrm{h}} \mathrm{k}^{\mathrm{h}} /$. In conversational speech, Ruch (2008:78) reports that $71.1 \%$ of tokens are postaspirated/postaffricated $\left(\left[\mathrm{t}^{\mathrm{h}}, \mathrm{t}^{\mathrm{s}}\right]\right) .11 \%$ of tokens have complete deletion, and $17.8 \%$ have some amount of preaspiration. This means that over half of the tokens listeners hear in daily life provide evidence for the metathesized order. Although non-metathesized variants are in the minority, I believe that sociolinguistically-conditioned variation is an important reason why the metathesized order is not 
phonologizing.

2.4 Morphophonemic alternations Alternations across word and morpheme boundaries also give learners evidence that $[\mathrm{s}],[\mathrm{h}]$, and $[\mathrm{h}]$ are phonologically-conditioned allophones of $/ \mathrm{s} /$, and that $/ \mathrm{s} / \mathrm{precedes}$ /C/ underlyingly. Morphemes and words with final /s/ are pronounced differently depending on the phonological context (Table 2). Within these alternations, there is also socially and stylistically conditioned variation (omitted from Table 2). Prevocalically, word-final $/ \mathrm{s} /$ is realized with $/ \mathrm{s} /$ in a single location that corresponds to its orthographic one. It surfaces as $[\mathrm{VsV}] \sim[\mathrm{VhV}]$ (Table $2 \mathrm{a} \sim$ Table $2 \mathrm{~b}$ ). Adjacent to /ptk/, word-final /s/ can be realized in its orthograpic location, before /ptk/, surfacing as [st] $\sim$ [ht] (Table 2e $\sim$ Table 2f). It can also be realized after $/ \mathrm{ptk} /$ as postaspiration (Table $2 \mathrm{~g}$ ). Deletion is also attested in both contexts (Table 2d, h) (Villena-Ponsoda, 2008).

Table 2: Phonological alternations across morpheme boundaries

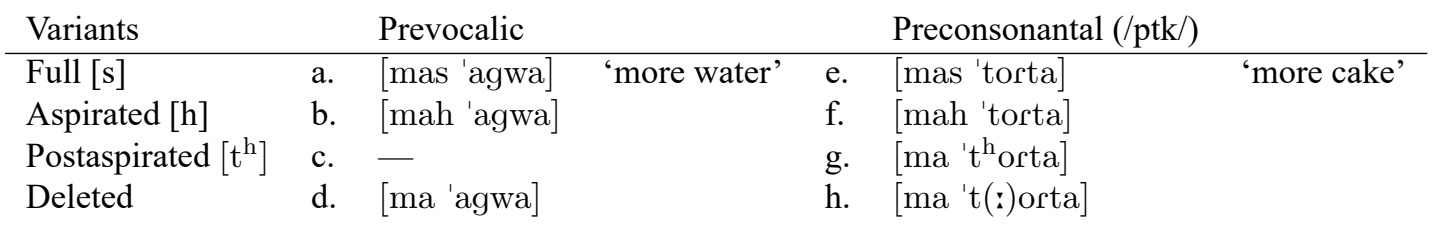

The phonologically-conditioned alternations provide listeners evidence that postaspiration is a cluster, where $/ \mathrm{s} /$ precedes $/ \mathrm{ptk} /$ in the underlying representation. From data like that in Table 2, learners deduce the following:

- Certain words like/mas/ have an underlying final/s/, because they surface with this final consonant ([s] or [h]) prevocalically and (less frequently) preconsonantally.

- When these words are followed by /ptk/-initial words, postaspiration is possible (/mas 'torta/ $\rightarrow$ [ma ' $\mathrm{t}^{\mathrm{h}}$ orta]). Thus, postaspiration arises from what learners know to be word-final /s/ and following word-initial /ptk/.

- Postaspiration in monomorphemic words likely derives from the same /st/ source, even though there are no phonological alternations to provide evidence for underlying preceding $/ \mathrm{s} /$. In monomorphemic contexts, sociolinguistic variation provides additional supporting evidence, since listeners hear both linear orders.

In the following section (Section 3), I present a perception experiment that tests perception of postaspiration in contexts where we know there to be an underlying $/ \mathrm{sC} /$ cluster, namely across word boundaries. The results show that Sevillian listeners perceive VOT and use it to give them information about the preceding word.

\section{Methods}

3.1 Materials and procedure The perception task takes advantage of the difference between 3SG and 2sG present tense verbs, which differ only in the presence of final /s/ ((3) vs. (4)). Mexican and Sevillian Spanish share underlying representations, but have different surface forms for $2 \mathrm{sG}$.
Juan / tjene- $\emptyset$ 'pali/.
[huan 'tjene 'pali] (Seville, Mexico)

Juan has-3SG pali.

Juan has pali.
Tú /tjene-s 'pali/.
[tu 'tjene ' $\mathrm{p}^{\mathrm{h}}$ ali] (Seville)
You have-2sG pali.
[tu 'tjenes 'pali] (Mexico)
You have pali.

Listeners hear short phrases like (5): the subject is removed, the verb has no [s], and VOT on the first consonant of the nonce word is manipulated. If listeners choose 'Tú' $(2 \mathrm{sG}, / \mathrm{s} /)$, this indicates they have reconstructed an underlying preceding /s/ on the verb; if they choose 'Juan' (3sG, no /s/), it suggests that they have not. 
(5)

$$
\begin{aligned}
& \text { Sample stimulus sentence } \\
& \text { Hear } * * * \text { ['tjene ' } \mathrm{p}^{\mathrm{h}} \text { ali] } \\
& \text { Answer choices: Juan (3SG) Tú (2SG) }
\end{aligned}
$$

The stimuli sentences consist of different combinations of subjects, verb forms, and nonce words. The nonce words are disyllabic with stress on the first syllable. The first consonant is $/ \mathrm{p} /, \mathrm{t} /$, or $/ \mathrm{k} /$; each of these

\begin{tabular}{|c|c|c|c|}
\hline & $/ \mathrm{p} /$ & $/ \mathrm{t} /$ & $/ \mathrm{k} /$ \\
\hline /a/ & /'pali/ & /'tali/ & /'kali/ \\
\hline /i/ & /'pina/ & /'tinu/ & /'kina/ \\
\hline$/ \mathrm{u} /$ & /'pumi/ & /'tumi/ & /'kuma/ \\
\hline
\end{tabular}
is followed by /a/, /i/, and /u/ (Table 3).

Table 3: Nonce words

A male native speaker from Seville recorded the nonce words embedded in sentences like (3) and (4). Recordings were done in a soundbooth at Rutgers University with a Zoom H4N Pro recorder and an AudioTechnica AT831b lapel microphone. The speaker is linguistically trained, and was instructed to produce postaspiration where appropriate. He was able to do so without difficulty. Each word was was recorded naturally in a full verbal present tense paradigm, providing material for test items, controls, and fillers. Before manipulation, the recorded sentences were normalized in intensity to $60 \mathrm{~dB}$ with a Praat script.

The test stimuli were created as illustrated in Table 4. Test sentences were constructed from two of the recorded frame sentences, one of which has underlying $/ \mathrm{s} /(4)$ and one of which does not (3). For each nonce word, there was such a pair of sentences (Table $4 \mathrm{a})$. I used the $3 \mathrm{sg}(\mathrm{no} / \mathrm{s} /$ ) sentence as the base sentence (Table $4 b)$. From this sentence, the subject was removed and replaced with a $30 \mathrm{~ms}$ pure tone, inserted immediately preceding the verb (Table $4 \mathrm{c})$. Then, the nonce word from the $2 \mathrm{sG}(/ \mathrm{s} /)$ sentence was spliced into this modified version at the zero-crossing of the burst of the nonce word (*** 'tjene | ' $\left.\mathrm{p}^{\mathrm{h}} \mathrm{ali}_{2}\right)($ Table $4 \mathrm{~d})$. This ensures that all other acoustic cues - like closure duration and duration of the vowel preceding the nonce word-remain the same as in the naturally-produced $3 \mathrm{sg}(\mathrm{no} / \mathrm{s} /)$ sentence. All test sentences have the nonce word that was

\begin{tabular}{|c|c|c|c|c|}
\hline & Two original sentences & $\begin{array}{l}\text { 1. Juan tiene pali } \\
\text { 2. Tú tienes pali } \\
2\end{array}$ & $\begin{array}{l}\text { [huan 'tjene 'pali] } \\
\text { [tu 'tjene 'ph ali] }\end{array}$ & \\
\hline b. & (1) is base sentence & Juan tiene pali ${ }_{1}$ & [huan 'tjene 'pali] & \\
\hline c. & Subject in (1) replaced with tone & $*$ tiene pali $_{1}$ & [* 'tjene 'pali] & \\
\hline d. & $\begin{array}{l}\text { Nonce word in (1) replaced with (2) } \\
\text { (natural postaspiration) }\end{array}$ & $*$ tiene pali 2 & [* 'tjene $\mathrm{p}^{\mathrm{h}}$ ali] & \\
\hline e. & 3 VOT steps created by removing VOT & & 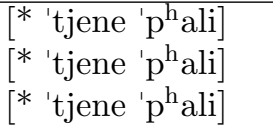 & $\begin{aligned} \text { VOT- } 2 & =67 \mathrm{~ms} \\
\text { VOT- } 1 & =39 \mathrm{~ms} \\
\text { VOT- } 0 & =10 \mathrm{~ms}\end{aligned}$ \\
\hline
\end{tabular}
originally recorded in the $2 \mathrm{sG}(/ \mathrm{s} /)$ context.

Table 4: Steps in stimuli creation for test sentences

From there, a VOT continuum was created on the nonce word by removing VOT (Table 4e). The nonce word recorded in the $2 \mathrm{sG}$ context has naturally long VOT, because it was recorded in a context following $/ s /$. The continuua were calculated independently for each nonce word sentence pair, since VOT differs by consonant and following vowel (Cho \& Ladefoged, 1999).

Table 5 shows example continuua. Each step reduced VOT by roughly half of the difference between the naturally produced intervocalic VOT in $3 \mathrm{sg}$ (no /s/) contexts, and the longer VOT produced in $2 \mathrm{sG}(/ \mathrm{s} /)$ contexts. VOT-2 is the longest, and was left as originally produced in $2 \mathrm{sG}$ contexts. VOT- 0 was shortened to approximately the duration of the normal intervocalic VOT. VOT-1 is halfway between VOT-2 and VOT- 0. The VOTs reported for Step 0 (shortened from long VOTs) are comparable to the intervocalic VOTs in 3sG (no /s/) contexts, and to those reported for other Spanish dialects (Rosner et al., 2000). The VOT-0 tokens are not identical to the original intervocalic VOTs because splicing out VOT sometimes required slight adjustments to hit zero-crossings. For similar reasons, the VOT steps are roughly equal but not identical. 
Table 5: VOT continua example for three nonce words

\begin{tabular}{|c|c|c|c|c|c|}
\hline UR & Intervocalic VOT (original) & /sC/ VOT (original) & VOT-0 & VOT-1 & VOT-2 (original) \\
\hline /pali/ & $11.0 \mathrm{~ms}$ & $66.7 \mathrm{~ms}$ & $9.41 \mathrm{~ms}$ & $38.9 \mathrm{~ms}$ & $66.7 \mathrm{~ms}$ \\
\hline tăali/ & $17.2 \mathrm{~ms}$ & $82.7 \mathrm{~ms}$ & $16.1 \mathrm{~ms}$ & $49.4 \mathrm{~ms}$ & $82.7 \mathrm{~ms}$ \\
\hline / & $22.7 \mathrm{~ms}$ & $96.6 \mathrm{~ms}$ & $22.7 \mathrm{~ms}$ & $60.1 \mathrm{~ms}$ & $96.6 \mathrm{~ms}$ \\
\hline
\end{tabular}

Test, control, and filler sentences for a single nonce word are illustrated in Table 6. For each of the 9 test words, there were 3 VOT versions ( $=27$ sentences). For these items, the answer choices were 'Juan' ( $3 \mathrm{SG})$ and 'Tú' (2SG). The fillers and controls were naturally produced sentences, with no modifications other than removing the subject. There were 18 control sentences consisting of each of the 9 nonce words in naturally produced $3 \mathrm{SG}$ and $2 \mathrm{SG}$ sentences, with the same answer choices. There were also 50 filler sentences consisting of 5 nonce words (pali, pumi, kuma, kina, tinu) with different combinations of subject choices that made the answer unambiguous. Controls (for Sevillian listeners) and fillers (for Mexican listeners) were used to ensure participants completed the task as required, and were later used to exclude those who had low accuracy on these items. In addition, controls and fillers distracted listeners from the test sentences and made the task easier for Mexican listeners. Listeners not familiar with postaspiration have difficulty perceiving it. Unambiguous fillers and controls kept these listeners engaged, because they had the linguistic knowledge to respond correctly to these items.

Table 6: Test, control, and filler items for pali. ([p] = VOT-0; ['ph $]=$ VOT-1; ['ph] = VOT-2/Naturally long)

\begin{tabular}{|c|c|c|c|c|c|}
\hline Type & Phrase recorded in & Word & Answer 1 & Answer 2 & Listeners hear \\
\hline Test & Juan tiene pali (3SG) & pali[VOT-0] & Juan & tú & [* 'tjene 'pali] \\
\hline \multirow[t]{2}{*}{ (3) } & Juan tiene pali (3SG) & pali[VOT-1] & Juan & tú & [* 'tjene ' $\mathrm{p}^{\mathrm{h}}$ ali] \\
\hline & Juan tiene pali (3SG) & pali[VOT-2] & Juan & tú & [* 'tjene 'phali] \\
\hline \multirow{2}{*}{$\begin{array}{l}\text { Controls } \\
\text { (2) }\end{array}$} & Juan tiene pali (3SG) & pali[orig] & Juan & tú & [* 'tjene 'pali] \\
\hline & Tú tienes pali (2sG) & pali[orig] & Juan & tú & [* 'tjene 'phali] \\
\hline \multirow{10}{*}{$\begin{array}{l}\text { Fillers } \\
(10)\end{array}$} & Juan tiene pali (3SG) & pali[orig] & Juan & nosotros & [* 'tjene 'pali] \\
\hline & Juan tiene pali (3SG) & pali[orig] & Juan & ellas & [* 'tjene 'pali] \\
\hline & Tú tienes pali (2sG) & pali[orig] & tú & nosotros & [* 'tjene p'hali] \\
\hline & Tú tienes pali (2sG) & pali[orig] & tú & ellas & [* 'tjene 'phali] \\
\hline & Nosotros tenemos pali (1PL) & pali[orig] & nosotros & tú & [* te'nemo 'phali] \\
\hline & Nosotros tenemos pali (1PL) & pali[orig] & nosotros & Juan & [* te'nemo 'phali] \\
\hline & Nosotros tenemos pali (1PL) & pali[orig] & nosotros & ellas & [* te'nemo 'phali] \\
\hline & Ellas tienen pali (3PL) & pali[orig] & ellas & tú & [* 'tjenen 'pali] \\
\hline & Ellas tienen pali (3PL) & pali[orig] & ellas & Juan & [* 'tjenen 'pali] \\
\hline & Ellas tienen pali (3PL) & pali[orig] & ellas & nosotros & [* 'tjenen 'pali] \\
\hline
\end{tabular}

The experiment was run online with PCIbex (Zehr \& Schwarz, 2018). Participants saw one practice item with a verb form that unambiguously revealed the subject. The test, control, and filler items were randomized for each participant. There were a total of 95 items, and the task lasted 10-30 minutes. After the experiment, participants completed a demographic form. They were paid for their time.

3.2 Participants 33 Sevillian listeners and 30 Mexican listeners participated in the experiment. Six participants were later excluded (see Section 3.4). Mexican Spanish listeners were recruited on Prolific (https://www.prolific.co/) and were of Mexican nationality, spoke Mexican Spanish as their first language, and resided in Mexico at the time of the experiment. Sevillian participants were recruited through social networks and personal contacts. Nine Sevillians had spent a year or more in a different country.

Participants whose data were analyzed were of similar mean ages $($ Mexico $=25.5$; Seville $=35.0)$, and were split by gender $($ Mexico $=7 \mathrm{~F} / 20 \mathrm{M} / 1$ preferred not to respond; Seville $=19 \mathrm{~F} / 10 \mathrm{M})$. The majority of participants in both countries had completed at least some tertiary education. In Seville, 15 also had done graduate work. Most participants reported proficiency in other languages ranging from beginning to advanced proficiency in English. Participants also reported knowledge of French, Portuguese, Italian, Catalan, German, Russian, and Japanese. Four Mexican listeners reported native English proficiency. 
3.3 Predictions To do the task, listeners must be able to (1) perceive postaspiration and (2) connect this postaspiration to the lexical representation of the verb.

Prediction 1: Sevillian listeners should base their responses on VOT. When VOT is shortest, they should choose $3 \mathrm{SG}(\mathrm{no} / \mathrm{s} /$ ) more than $2 \mathrm{sG}(/ \mathrm{s} /)$. When VOT is longest, they should choose $2 \mathrm{sG}(/ \mathrm{s} /)$ more than $3 \mathrm{sG}$

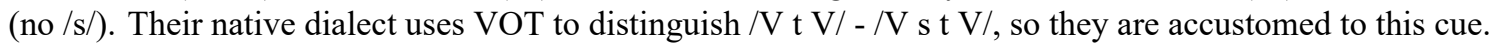

Prediction 2: Mexican listeners should not base their choice of subject on VOT, and are expected to have a strong preference for $3 \mathrm{sG}(\mathrm{no} / \mathrm{s} /)$ at all VOT steps. Although their dialect shares the same lexical representation of the verb as Sevillian Spanish (/'tjene-s/), Mexican Spanish does not aspirate coda /s/. Undoing postaspiration requires recognizing metathesis, and then recognizing $[\mathrm{h}]$ as an allophone of $/ \mathrm{s} /$. Previous research establishes that listeners of non-aspirating dialects have low accuracy at perceiving coda [h] (Schmidt, 2013). If Mexican listeners do not perceive aspiration, they cannot use it to reconstruct an underlying $/ \mathrm{s} /$.

Predictions are schematized in Table 7 ( $>$ indicates preference for the item on the left; $<$ indicates preference for the item on the right; $\approx$ indicates no preference).

Table 7: Predicted response patterns for Sevillian and Mexican listeners $(2 \mathrm{sG}=/ \mathrm{s} / ; 3 \mathrm{sG}=\mathrm{no} / \mathrm{s} /)$

$\begin{array}{llll}\text { VOT Step } & \text { VOT-0 } & \text { VOT-1 } & \text { VOT-2 } \\ \text { Seville } & 3 \mathrm{SG}>2 \mathrm{SG} & 3 \mathrm{SG} \approx 2 \mathrm{SG} & 3 \mathrm{SG}<2 \mathrm{SG} \\ \text { Mexico } & 3 \mathrm{SG}>2 \mathrm{SG} & 3 \mathrm{SG}>2 \mathrm{SG} & 3 \mathrm{SG}>2 \mathrm{SG}\end{array}$

3.4 Statistical analysis The data were analyzed in a logistic mixed-effects regression in R (RCoreTeam, 2020), with the BOBYQA optimizer. The lmerTest package was used to calculate $p$ values (Kuznetsova et al., 2017). The model was run only on test items, and predicts the response (2SG vs. 3sG) from Condition (VOT0 , VOT-1, VOT-2), Region (Seville, Mexico), and their interaction. VOT-0 and Mexico are the baselines. The model also contains a random intercept for participant. Because there were significant interactions involving Region, separate models were then run to investigate the effect of VOT step in each region. Posthoc comparisons between levels of factors were run with emmeans (with Tukey adjustment for multiple comparisons) (Lenth, 2020).

Six participants were excluded. Four Sevillian participants were excluded for accuracy below $75 \%$ on the control items (50\%-66\% accuracy), which were unmanipulated recordings of $2 \mathrm{sg}$ and 3sG sentences (with the subject removed). Sevillians should perform well on these natural recordings of their native dialect. For Mexican listeners, fillers (with unambiguous answers) were used instead as exclusion criteria. Two Mexican listeners were removed for accuracy lower than $75 \%$ on filler items. Control items were not used to exclude Mexican listeners because aspiration and gemination are the only cues to the subject in these items. Low accuracy likely reflects lack of familiarity with these cues, rather than lack of attention.

\section{Results}

Figure 1 shows the results by VOT step for Mexico and Seville. Results for Seville are in the left panel of Figure 1. Sevillian listeners respond to VOT and interpret it as a morphological distinction marked by preceding /s/ on the verb. At the shortest VOT step, they give mostly $3 \mathrm{sg}(\mathrm{no} / \mathrm{s} /)$ responses $(89 \%)$ and rarely $2 \mathrm{sG}(/ \mathrm{s} /)$ responses $(11 \%)$. At the middle VOT step, they are equally likely to respond with $3 \mathrm{sG}(\mathrm{no} / \mathrm{s} /)$ and $2 \mathrm{sG}(/ \mathrm{s} /)$ responses. At the longest VOT step, their responses are almost a mirror image of the shortest VOT step, with $78 \% 2 \mathrm{sg}(/ \mathrm{s} /)$ responses and $22 \% 3 \mathrm{sg}(\mathrm{no} / \mathrm{s} /$ ) responses. Sevillian listeners use VOT as information about the morphological distinction between $2 \mathrm{sG}$ and $3 \mathrm{sG}$ verb forms, and use it to determine the subject.

Mexican listeners' responses (Figure 1, right panel) differ drastically from Sevillian listeners'. They respond $3 \mathrm{sg}(\mathrm{no} / \mathrm{s} /)$ at rates higher than $75 \%$ at all VOT steps, while $2 \mathrm{sG}(/ \mathrm{s} /)$ responses range from $10 \%$ $18 \%$, even at the longest VOT step. There is a slight increase in $2 \mathrm{sG}(/ \mathrm{s} /)$ responses in VOT-1 and VOT-2, but these responses are still well below chance. Mexican listeners do not consistently parse postaspiration as morphological information about the preceding verb. 


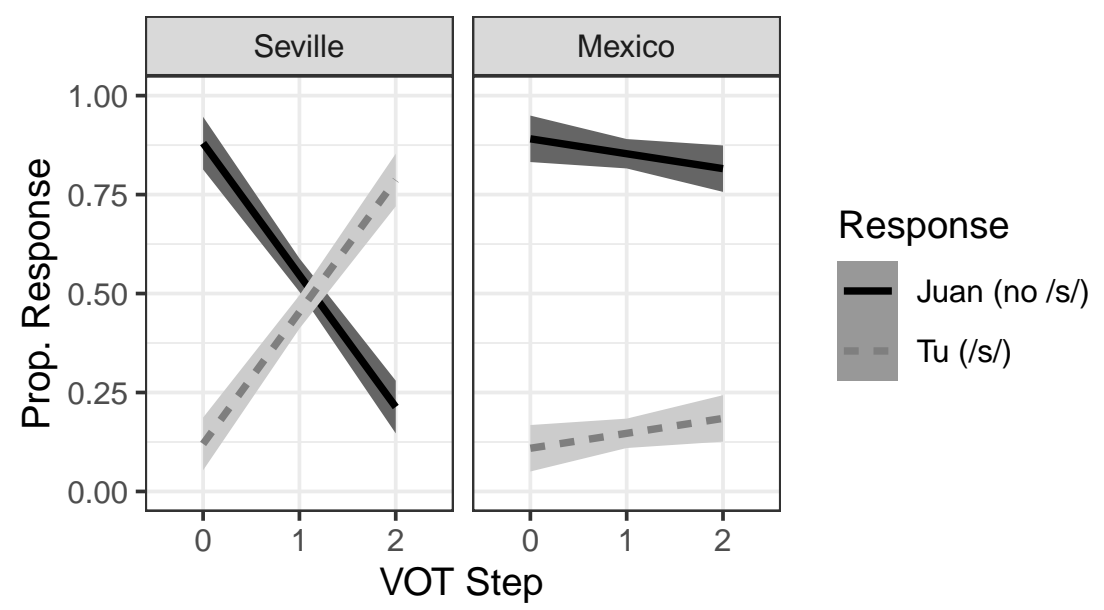

Figure 1: Response rate at each VOT step for Sevillian Mexican participants

The model (Table 8) confirms these results. There is a significant two-way interaction between condition and region, such that longer VOT has a stronger effect on boosting $2 \mathrm{sG}(/ \mathrm{s} /)$ responses in Seville than in Mexico, at VOT-1 $(\beta=1.66, p<.001)$ and VOT-2 $(\beta=3.125, p<.001)$. For Mexican listeners, longer VOT affects the proportion of $2 \mathrm{sG}(/ \mathrm{s} /)$ responses much less than for Sevillian listeners.

Table 8: Model results for Mexico and Seville predicting 2sG (/s/) responses

\begin{tabular}{rrrrrl}
\hline & Estimate & Std. Error & $\mathrm{z}$ value & $\operatorname{Pr}(>|\mathrm{z}|)$ & \\
\hline (Intercept) & -2.663 & 0.313 & -8.515 & 0.000 & $* * *$ \\
VOT-1 & 0.562 & 0.282 & 1.995 & 0.046 & $*$ \\
VOT-2 & 0.727 & 0.277 & 2.622 & 0.009 & $* *$ \\
Seville & 0.283 & 0.422 & 0.670 & 0.503 & \\
VOT-1:Seville & 1.660 & 0.376 & 4.415 & 0.000 & $* * *$ \\
VOT-2:Seville & 3.125 & 0.391 & 7.984 & 0.000 & $* * *$ \\
\hline
\end{tabular}

Table 9: Model results for Seville

\begin{tabular}{rrrrrr}
\hline & Est. & SE & $\mathrm{z}$ value & $\operatorname{Pr}(>|\mathrm{z}|)$ & \\
\hline (Int.) & -2.33 & 0.26 & -8.85 & 0.00 & $* * *$ \\
VOT-1 & 2.18 & 0.25 & 8.78 & 0.00 & $* * *$ \\
VOT-2 & 3.76 & 0.28 & 13.55 & 0.00 & $* * *$ \\
\hline
\end{tabular}

Table 10: Model results for Mexico

\begin{tabular}{rrrrl}
\hline Est. & SE & z value & $\operatorname{Pr}(>|z|)$ & \\
\hline-2.84 & 0.38 & -7.50 & 0.00 & $* * *$ \\
0.58 & 0.28 & 2.03 & 0.04 & $*$ \\
0.75 & 0.28 & 2.67 & 0.01 & $* *$ \\
\hline
\end{tabular}

Within each listener group, the effects of VOT step also differ. For Sevillian listeners (Table 9), VOT step is significant: Sevillians give more 2 sG responses at VOT-1 than at VOT-0 $(\beta=2.18, p<.001)$, and more at VOT-2 than at VOT-1 (from emmeans post-hoc test: $\beta=1.58, p<.001$ ). For Mexican listeners, there is also a significant effect of VOT step (Table 10). Mexican listeners give more 2 sG responses at VOT-1 than at VOT-0 $(\beta=.58, p<.05)$ and more at VOT-2 than at VOT-0 $(\beta=.75, p<.01)$. Post-hoc tests show that, unlike Seville, the rate of $2 \mathrm{sG}$ responses is not significantly different at VOT-1 and VOT-2 $(\beta=.17, p=.78)$. While Mexican listeners may be able to perceive that postaspiration differs from a very short VOT, they do not clearly use this as information about the subject. The effect size is much smaller than for Seville.

4.1 Results summary The results are in line with the predictions. Sevillian listeners hear postaspiration and parse it as underlying preceding /s/, which they then interpret as a morphological distinction. Mexican listeners do not consistently parse postaspiration as underlying preceding /s/, responding mostly $3 \mathrm{sG}$ at all VOT steps. They do not 'undo' postaspiration to reconstruct underlying preceding /s/. 
However, the Mexican listeners do show a slight increase in 2sG responses at longer VOT steps. An examination of individual results shows that four participants had higher rates of $2 \mathrm{sG}$ responses than $3 \mathrm{sG}$ responses at the longest VOT step. At VOT-2, their rates of $2 \mathrm{sg}$ were $55 \%$ and $66 \%$. For comparison, 20 Sevillian listeners chose $2 \mathrm{sg}$ at a rate of $75 \%$ or higher at VOT-2. None of the Mexican participants whose response pattern changed by VOT reported contact with people in Southern Spain, or having lived outside Mexico. There are several possibile explanations for their sensitivity to VOT. One possibility is that they may be able to hear postaspiration to a degree. For some reason, some listeners are able to map postaspiration back to an underlying / $\mathrm{sC}$ / cluster. Another possibility is that Mexican listeners hear postaspirated forms as noncanonical, and choose $2 \mathrm{sG}$ because they know postaspiration is not an acceptable realization following $3 \mathrm{sG}$ verbs. A final possibility is that these listeners have some contact with Andalusian Spanish through sources not captured in the demographic questionnaire (e.g. TV, movies, social media).

\section{Analysis sketch}

5.1 Analysis outline In this section, I outline a serial analysis that treats postaspiration as the result of gradual coda /s/ reduction, and metathesis based on possible perceptual motivations.

Postaspiration can be analyzed as gradual coda /s/ reduction and metathesis (Ruch, 2013). As discussed in Section 2.2, varieties of Spanish differ in whether preconsonantal coda /s/ surfaces as [s], [h], [Ø] or $[\mathrm{h}]$, and most varieties allow multiple allophonic variants. The steps in the serial analysis correspond to different dialects, and also to different allophonic variants within the same dialect. Mexican and Sevillian Spanish represent a conservative (permissive) and non-conservative (restrictive) dialect, respectively (Table 11). Mexican Spanish allows preconsonantal /s/ to surface faithfully, while Sevillian Spanish reduces preconsonantal /s/ in a variety of ways depending on social, linguistic, and stylistic factors (e.g. ['paht(:)a], ['pat:a], ['pat $\left.(:)^{\mathrm{h}} \mathrm{a}\right]$; Ruch, 2008). I focus on metathesis (see Martínez-Paricio \& Lloret (2017) for an analysis of aspiration, deletion, and gemination).

Table 11: Steps in a serial analysis

Step 0: UR

Step 1: Faithful mapping

Step 2: Aspiration (debuccalization)

Step 3: Metathesis /pasta/

['pasta] (e.g. Mexican Spanish)

['pahta] (e.g. Argentinian Spanish)

['pat ${ }^{\mathrm{h}} \mathrm{a}$ (Sevillian Spanish)

In my analysis, coda /s/ reduction is compelled by constraints on place features in coda position (Hualde, 1987; McCarthy, 2008). ${ }^{2}$ As coda /s/ loses its place features, it surfaces as debuccalized (placeless) [h] $((/$ pasta $/) \rightarrow$ ['pahta $])$. Coda $[\mathrm{h}]$ is the preferred outcome in some dialects of Spanish (e.g. Argentinian, Terrell, 1978). However, other dialects do not tolerate even placeless coda [h]. One solution is to delete it, which is a frequent path in varieties like Dominincan Spanish (['pata]) (Alba, 1990). Another solutionused in Sevillian Spanish - is to metathesize /s ptk/ sequences. The resulting form ['pat $\left.{ }^{\mathrm{h}} \mathrm{a}\right]$ accomplishes two goals: it maintains the laryngeal features and removes the coda in the preceding syllable.

Sevillians go through the steps in Table 11 backwards to reconstruct underlying /s ptk/ (Step 0) from surface $\left[\mathrm{p}^{\mathrm{h}}\right]$ (Step 3). First, they perceive postaspiration. Second, they recognize it as a metathesized form of [hp]. Finally, they recognize [h] as an allophonic variant of $/ \mathrm{s} /$. On the other hand, Mexican listeners may not be able to 'undo' postaspiration. Given surface $\left[\mathrm{p}^{\mathrm{h}}\right]$, they may not hear $[\mathrm{h}]$ at all, preventing them from recognizing $\left[\mathrm{p}^{\mathrm{h}}\right]$ as metathesis. If they do not recognize metathesis, they do not arrive at [hp], which is a necessary step in identifying underlying /s/.

5.2 Perceptual motivations Why is metathesis a possible resolution of coda /s/ in Sevillian Spanish? There may be perceptual reasons that listeners (1) perceive postaspiration more easily than preaspiration; (2) misperceive aspiration (presence vs. absence and linear order); (3) favor postaspiration over preaspiration specifically for voiceless stops.

First, preaspiration may be more difficult to perceive than postaspiration (Bladon, 1986; Kingston, 1990;

2 Coda /s/ reduction has been analyzed extensively, and other scholars use different features and mechanisms to compel reduction (e.g. Kaisse, 1996; Morris, 2000; Shepherd, 2003). 
Silverman, 2003). This is argued to be one of the reasons that preaspiration is cross-linguistically rare, while postaspiration (on voiceless stops) is much more common.

Second, there is cross-linguistic evidence that the presence and linear order of aspiration is difficult to perceive, which could lead to both synchronic alternations and diachronic changes. Synchronically, listeners misperceive the presence and location of [h] (e.g. Mielke, 2003). This difficulty may partially explain why many attested synchronic metathesis patterns and diachronic changes involve aspiration. For example, languages including Balangao, Cebuano, and Cherokee have synchronic metathesis involving aspiration (see Yoon, 2012 for typology). Marathi provides an example of a diachronic change: aspiration shifted to word-initial position from the onset of the second syllable (Blevins \& Garrett, 2004:133). These patterns of synchronic metathesis and diachronic change may arise from listeners' misperception of the location of aspiration, as aspiration has 'elongated' phonetic cues that span multiple segments (Blevins \& Garrett, 2004; Yoon, 2012).

Third, postaspiration may be limited to /s ptk/ sequences because voiceless stops provide a perceptually beneficial place to dock [h]. For example, in Cherokee and Korean, a mobile aspiration feature docks on stops as postaspiration. However, in sequences with sonorants, $[\mathrm{h}]$ deletes instead. This differential behaviordocking on voiceless stops but deleting around sonorants - is argued to be perceptually motivated. Docking $[\mathrm{h}]$ on a stop release is perceptually beneficial, while 'docking' it at the offset of a sonorant is not (Kingston, 1990; Cho, 2012; Yoon, 2012). Sevillian postaspiration is similar to patterns in Cherokee and Korean. It is limited to /s ptk/ clusters, at least in the form of VOT. Sequences with sonorants and voiced stops (e.g. $/ \mathrm{s} \mathrm{mnl} /, / \mathrm{s} \mathrm{bdg} /$ ) may show devoicing following $/ \mathrm{s} /$, or $/ \mathrm{s} /$ may delete entirely (Martinez-Gil, 2012). In either case, they lack a period of aspiration following the second consonant. Devoicing suggests some kind of gestural realignment in these clusters, but more phonetic work is needed to determine its nature. Sevillian postaspiration may be motivated by similar perceptual factors as in Cherokee and Korean: metathesis is limited to /s ptk/ clusters because these are the only ones where full metathesis is perceptually beneficial.

Variants of Spanish coda /s/ are usually analyzed being in stable variation, but postaspiration provides evidence to the contrary, for at least this dialect (Ruch \& Peters, 2016). If aspiration is difficult for Spanish speakers to perceive, as it is for speakers of other languages, then Spanish aspiration may be susceptible to change. Indeed, aspiration seems to be perceptually difficult for Spanish speakers. Many dialects delete coda $/ \mathrm{s} /$ entirely instead of maintaining a perceptually weak coda $[\mathrm{h}]$, and even speakers of dialects with aspiration perceive it less accurately than other consonants (Schmidt, 2013; Bedinghaus, 2015). Postaspiration avoids perceptually weak preaspiration, maintains features of $/ \mathrm{s} /$, and satisfies coda restrictions by creating an open syllable.

\section{Summary}

In this paper, I have argued that postaspiration in Sevillian Spanish is representationally a cluster, and that Sevillian listeners perceive it as such. Because postaspiration occurs across morpheme and word boundaries, Sevillian learners have evidence that postaspiration is a phonologically- and sociolinguistically-conditioned variant that arises from $/ \mathrm{s} \mathrm{ptk/clusters.} \mathrm{This} \mathrm{evidence} \mathrm{prevents} \mathrm{them} \mathrm{from} \mathrm{analyzing} \mathrm{postaspirated} \mathrm{stops} \mathrm{as}$ complex segments $/ \mathrm{p}^{\mathrm{h}} \mathrm{t}^{\mathrm{h}} \mathrm{k}^{\mathrm{h}} /$. In perception, Sevillian listeners 'undo' postaspiration to arrive at an underlying $/ \mathrm{s} \mathrm{ptk} /$ representation. Listeners of other dialects do not perceive postaspiration as metathesis, and may also have difficulty perceiving $[\mathrm{h}]$ as an allophone of /s/. I also sketched a serial analysis in which postaspiration is the result of coda /s/ reduction and metathesis. The motivation behind Sevillian postaspiration may be, in part, cross-linguistic perceptual difficulty with aspiration. Further investigation of Sevillian postaspiration can shed light on the nature of phonologization and metathesis, and how the two interact.

\section{References}

Alba, Orlando (1990). Variación fonética y diversidad social en el español dominicano de Santiago. Pontificia Universidad Católica Madre y Maestra, Santiago.

Beddor, Patrice Speeter (2009). A coarticulatory path to sound change. Language 85:4, 785-821.

Bedinghaus, Robert William (2015). The effect of exposure to phonological variation on perceptual categorization and lexical access in second language Spanish: The case of $/$ s/-aspiration in Western Andalusian Spanish. $\mathrm{PhD}$ Dissertation, Indiana University, Bloomington.

Bladon, Anthony (1986). Phonetics for hearers. McGregor, Graham (ed.), Language for hearers, Pergamon Press, Great Britain, 1-24. 
Blevins, Juliette \& Andrew Garrett (2004). The evolution of metathesis. Hayes, Bruce, Donca Steriade \& Robert Kirchner (eds.), Phonetically based phonology, Cambridge University Press, New York, 117-156.

Brown, Esther L. \& Rena Torres Cacoullos (2003). Spanish /s/: A different story from beginning (initial) to end (final). Núñez-Cedeño, Rafael, Luis López \& Richard Cameron (eds.), A Romance perspective on language knowledge and use. Selected papers from the XXXI Linguistic Symposium on Romance Languages (LSRL), Chicago, 19-22 April 2001, John Benjamins Publishing Company, Amsterdam/Philadelphia, vol. 238 of Current Issues in Linguistic Theory, 21-38.

Buizza, Emanuela \& Leendert Plug (2012). Lenition, fortition and the status of plosive affrication: The case of spontaneous RP English /t/. Phonology 29:1, 1-38.

Campos-Astorkiza, Rebeka (2003). Compensatory lengthening as root number preservation. Hajicová, E., A. Kotesovcová \& J. Mirovský (eds.), Proceedings of the XVII International Congress of Linguists, Matfyzpress, MFF UK, Prague.

Campos-Astorkiza, Rebeka (2016). Procesos fonológicos. Gutiérrez-Rexach, Javier (ed.), Enciclopedia de lingüistica hispánica, vol. 1, 847-858.

Cho, Hyesun (2012). Laryngeal feature mobility in Cherokee and Korean. Language and Linguistics 56, $283-306$.

Cho, Taehong \& Peter Ladefoged (1999). Variation and universals in VOT: Evidence from 18 languages. Journal of Phonetics 27, 207-229.

Del Saz, María (2019). From postaspiration to affrication: New phonetic contexts in Western Andalusian Spanish. Calhoun, Sasha, Paola Escudero, Marija Tabain \& Paul Warren (eds.), Proceedings of the 19th International Congress of Phonetic Sciences, Melbourne, Australia 2019, Australasian Speech Science and Technology, Canberra, Australia, $760-764$.

Erker, Daniel (2012). An acoustically based sociolinguistic analysis of variable coda /s/ production in the Spanish of New York City. PhD Dissertation, New York University, New York.

Gerfen, Chip (2001). A critical view of licensing by cue: Codas and obstruents in Eastern Andalusian Spanish. Segmental phonology in Optimality Theory, Cambridge University Press, 183-205.

Gerfen, Chip (2002). Andalusian codas. Probus 14, 247-277.

Gylfadottir, Duna (2015). An investigation of Andalusian stop cluster post-aspiration in naturalistic speech.

Horn, Meagan E. (2013). An acoustic investigation of postaspirated stops in Seville Spanish. Master's thesis, The Ohio State University, Columbus, $\mathrm{OH}$.

Hualde, José I. (1987). Delinking processes in Romance. Kirschner, Carl \& Janet Decesaris (eds.), Selected papers from the 17th Linguistic Symposium on Romance Languages (LSRL XVII) Rutgers University, 27-29 March 1987, Studies in Romance Linguistics, John Benjamins Publishing Company, Amsterdam/Philadelphia, 177-193.

Hualde, José Ignacio (2005). The Sounds of Spanish. Cambridge University Press, New York.

Hyman, Larry M. (2013). Enlarging the scope of phonologization. Yu, Alan C. L. (ed.), Origins of sound change: Approaches to phonologization, Oxford University Press, 3-28.

Kaisse, Ellen (1996). The prosodic environment of s-weakening in Argentinian Spanish. Grammatical theory and Romance linguistics: Selected papers from the 25th Linguistic Symposium on Romance Languages (LSRL XXV), John Benjamins Publishing Company, Seattle, WA, 123-134.

Kingston, John (1990). Articulatory binding. Kingston, J. \& M. E. Beckman (eds.), Papers in laboratory phonology 1: Between the grammar and physics of speech, Cambridge University Press, Cambridge.

Kuznetsova, Alexandra, Per B. Brockhoff \& Rune H. B. Christensen (2017). lmerTest package: Tests in linear mixed effects models. Journal of Statistical Software 82:13, 1-26.

Lenth, Russell (2020). emmeans: Estimated Marginal Means, aka Least-Squares Means. URL https://CRAN.R-project. org/package=emmeans.

Martinez-Gil, Fernando (2012). Main phonological processes. Hualde, Jose Ignacio, Antxon Olarrea \& Erin O'Rourke (eds.), The handbook of Hispanic Linguistics, Blackwell Handbooks in Linguistics, Wiley Blackwell, Hoboken, NJ, 111-131.

Martínez-Paricio, Violeta \& Maria-Rosa Lloret (2017). /s/-weakening in Andalusian Spanish: From (partial) deletion to (in)complete gemination.

McCarthy, John J. (2008). The gradual path to cluster simplification. Phonology 25, 271-319.

Mielke, Jeff (2003). The interplay of speech perception and phonology: Experimental evidence from Turkish. Phonetica 60, 208-229.

Morris, Richard E. (2000). Constraint interaction in Spanish/s/-aspiration: Three peninsular varieties. Hispanic linguistics at the turn of the millennium: Papers from the 3rd Hispanic Linguistics Symposium, Cascadilla Press, Somerville, MA.

Moya Corral, Juan Antonio (2007). Noticia de un sonido emergente: La africada dental procedente del grupo -st- en Andalucía. Revista de Filología 25, 457-465.

O’Neill, Paul (2009). S-aspiration and occlusives in Andalusian Spanish: Phonetics or phonology? Oxford University Working Papers in Linguistics, Philology \& Phonetics 12, 73-85.

O’Neill, Paul (2010). Variación y cambio en las consonantes oclusivas del español de Andalucía. Estudios de fonética experimental XIX, 11-41. 
Parrell, Benjamin (2012). The role of gestural phasing in Western Andalusian Spanish aspiration. Journal of Phonetics $40,37-45$.

Penny, Ralph (2000). Variation and change in Spanish. Cambridge University Press, Cambridge.

RCoreTeam (2020). R: A language and environment for statistical computing. URL https://www.R-project.org.

Riehl, Anastasia (2008). The phonology and phonetics of nasal obstruent sequences. PhD Dissertation, Cornell University, Ithaca, NY.

Rosner, Burton S., Luis López-Bascuas, José E. García-Albea \& Richard P. Fahey (2000). Voice-onset times for Castilian Spanish initial stops. Journal of Phonetics 28, 217-224.

Ruch, Hanna (2008). La variante [ts] en el español de la Ciudad de Sevilla: Aspectos fonético-fonológicos y sociolingüísticos de un sonido innovador. Master's thesis, University of Zürich, Zürich, Germany.

Ruch, Hanna (2012). Affrication of /st/-clusters in Western Andalusian Spanish: variation and change from a sociophonetic point of view. Calamai, S., C. Celata \& L. Ciucci (eds.), Proceedings of Sociophonetics, at the crossroads of speech variation, processing and communication, Pisa, December 14th-15th, 2010, Edizioni della Normale, 61-64.

Ruch, Hanna (2013). Investigating a gradual metathesis: Phonetic and lexical factors on /s/ aspiration in Andalusian Spanish. University of Pennsylvania Working Papers in Linguistics: Selected Papers from NWAV 41 19:2, 171-180.

Ruch, Hanna \& Jonathan Harrington (2014). Synchronic and diachronic factors in the change from pre-aspiration to postaspiration in Andalusian Spanish. Journal of Phonetics 45, 12-25.

Ruch, Hanna \& Sandra Peters (2016). On the origin of post-aspirated stops: Production and perception of /s/ + voiceless stop sequences in Andalusian Spanish. Laboratory Phonology 7:1, 1-36.

Schmidt, Lauren (2013). Regional variation in the perception of sociophonetic variants of Spanish /s/. Carvalho, Ana Maria \& Sara Beaudrie (eds.), Selected proceedings of the 6th Workshop on Spanish Sociolinguistics, Cascadilla Proceedings Project, Somerville, MA, 189-202.

Shepherd, Michael Andrew (2003). Constraint interactions in Spanish phonotactics: An Optimality Theory analysis of syllable-level phenomena in the Spanish language. Master's thesis, California State University, Northridge, CA.

Silverman, Daniel (2003). On the rarity of pre-aspirated stops. Journal of Linguistics 39:3, 575-598.

Stanton, Juliet (2017). Constraints on the distribution of nasal-stop sequences: An argument for contrast. PhD Dissertation, MIT, Cambridge, MA.

Terrell, Tracy D. (1978). La aspiración y elisión de /s/ en el español porteño. Anuario de Letras: Lingüística y Filología $16,41-66$.

Torreira, Francisco (2006). Coarticulation between aspirated-s and voiceless stops in Spanish: An interdialectal comparison. Sagarra, Nuria \& Almeida Jacqueline Toribio (eds.), Selected proceedings of the 9th Hispanic Linguistics Symposium, Cascadilla Proceedings Project, Somerville, MA, 113-120.

Torreira, Francisco (2012). Investigating the nature of aspirated stops in Western Andalusian Spanish. Journal of the International Phonetic Association 42:1, 49-63.

Villena-Ponsoda, Juan Andrés (2008). Sociolinguistic patterns of Andalusian Spanish. International Journal of the Sociology of Language 2008:193/194, URL https://www.degruyter.com/doi/10.1515/IJSL.2008.052.

Yoon, Tae-Jin (2012). Laryngeal metathesis as perceptual optimization. Studies in Phonetics, Phonology and Morphology $18: 3,413-435$.

Zehr, Jeremy \& Florian Schwarz (2018). PennController for Internet Based Experiments (IBEX). URL https://doi.org/10. 17605/OSF.IO/MD832. 